\title{
EFFECT OF SEEDING RATES OF FAHL BERSEEM MIXED WITH WHEAT UNDER THREE RATES OF NITROGEN FERTILIZER ON YIELD AND YIELD COMPONENTS OF BOTH CROPS
}

Abdel-Zaher, Sh.R. ;M.A. Abdel-Galil and Sahar T.lbrahim Crop intensification Res., Sec., Field Crops Res. Inst., Agric. Res. Center, Egypt.

\begin{abstract}
Two field trials were conducted at Sers EL-Lian Experiment Station during $2006 / 2007$ and $2007 / 2008$ to study the effect of fahl berseem mixed with wheat under three densities of fahl berseem $(15,25$ and $35 \%$ ) of the recommended rate of fahl berseem $\left(20 \mathrm{~kg} \mathrm{fed}^{-1}\right)$. Each rate was mixed with the recommended rate of wheat seed $\left(60 \mathrm{~kg} \mathrm{fed}^{-1}\right)$ and fertilized by three rates of nitrogen fertilizer, i.e., $100 \%$ of the recommended rate of $\mathrm{N}$ for wheat $\left(75 \mathrm{~kg} \mathrm{Nfed}^{-1}\right), 75 \%\left(56.25 \mathrm{~kg} \mathrm{Nfed}^{-1}\right)$ and $50 \%$ of the recommended rate $\left(37.5 \mathrm{~kg} \mathrm{Nfed}^{-1}\right)$ on growth, yield and yield components of both crops in the mixture. The data showed that all values of wheat characters significantly decreased by increasing the percentage of fahl berseem seeding rates when mixed with wheat, whereas, opposite trend was found by increasing nitrogen rates. The data also revealed that all fahl berseem characters significantly increased by increasing percentage of fahl berseem when mixed with wheat or by increasing nitrogen rates. Data also, indicated that mixing $35 \%$ of fahl berseem seeds with wheat fertilized by the recommended rate $\left(75 \mathrm{~kg} \mathrm{~N} \mathrm{fed}^{-1}\right)$ gave the best land equivalent ratio (LER) and total income. Soil sustainability increased as indicated by chemical properties of the soil. Chemical analysis revealed increased values of organic matter, available nitrogen, phosphorus and potassium when growing mixtures as compared with growing wheat only. In the $2 \mathrm{yr}$, fahl berseem was more competitive than wheat.
\end{abstract}

Keywords: mixed cropping, wheat, fahl berseem, land equivalent ratio

\section{INTRODUCTION}

Legume-cereal mixture is an important sustainable technology compared with continuous cereal cropping, it can increase the stability of soil aggregates, increase available nitrogen and organic mater and decrease soil erosion (Jankauskas and Janksuskiene 2003). Leguminous forage crops with cereals and adding phosphorus fertilizer has permitted agrosystems to develop healthy (Cantero-Martineg et al., 1995). Moreover, a forage grain mixture has played an important role in conserving the soil water and fertilizer in dry land agrosystems (Schwab et al., 1996).

As far back to the literatures the impotence of mixing berseem with cereals which lead to decrease the effect of the heavy competitive pressure of berseem against other strategic winter crops such as wheat and faba been and also lower the variability of annual return between mixtures and cereal monoculture to minimum was supported by Norman (1972). Several investigators studied optimum rates of mixture components. Hussain and Abdel-Latif (1982) found that the optimum seeding rate of berseem was $30 \mathrm{Kg}$ fed ${ }^{-1}$ when mixed with $15 \mathrm{~kg} \mathrm{fed}^{-1}$ of barley, produced higher green and dry matter yield. Gabra et al. (1984) found that mixture of berseem and barley 
produced as nearly the same as the pure stand berseem. In this concern, Nor EL-Din et al. (1984) reported also in another study that the yield of berseem and barley mixtures were higher than yield of the legume or none legume pure stand. They also found that legume-none legume mixtures also contained higher percent of protein than barley grown alone. EL-Hattab et al. (1985) found that berseem-barley mixture was comparatively superior in green and dry forage yields than mixtures of ryegrass and wheat or oats. Seif and Sedhom (1988) found also that fahl berseem-oats mixture was superior to mixtures of fahl berseem with tritical or barley. Abou- Kerisha, et al. (1996) indicated that seeding $75 \%, 50 \%$ and $25 \%$ fahl berseem, plus $25 \%, 50 \%$ and $75 \%$ barley in complement mixtures gave more yield than pure fahl berseem. They also evidenced that mixing fahl berseem with barley resulted in higher values barley traits as compared to pure stand barley. Mahrous et al. (1998) found that intercropping lentil with wheat decreased grain, seed and straw yields, seed index for both crops, and number of grains/spike for wheat and number of branches of lentil. Banik et al. (2006) reported that chickpea yield was significantly increased when it was intercropped with wheat and facilitated an increase in nodule number and dry weight as well as, root length of chickpea. These findings suggest that intercropping wheat and chickpea increased total productivity per unit area and improved land use efficiency. On the other hand, Thorsted et al. (2006) showed that intercropping of winter wheat and white clover decreased wheat grain yield by $10-25 \%$ as compared with wheat sole cropping. Abou-Kerisha et al. (2008) reported that intercropping wheat with faba bean or fahl berseem resulted in increased yield components of wheat.

The objectives of this study render us increasing fahl berseem seed production which we suffer a great deficit, in addition to a sustainable cropping system offered by a cereal-legume mixture, as well as, increasing soil fertility.

\section{MATERIALS AND METHODS}

Two field trials were carried out at Sers El-Lian Experiments station, during 2006/2007 and 2007/2008 seasons. The objective of this study was to investigate the effect of mixing fahl berseem (Trifoliumm alexandrinum L.) and wheat (Triticum aestivum L.) under three nitrogen fertilizer rates on yield and its components of both crops.

The Physical and chemical analysis of the experimental soil at a depth of 0 $30 \mathrm{~cm}$ was shown in Table1. 
Table 1:Physical and chemical analysis of the experimental soil at 0 $30 \mathrm{~cm}$ depth.

\begin{tabular}{|l|c|}
\hline Mechanical analysis & \\
Coarse sand \% & 1.39 \\
Fine sand \% & 31.48 \\
Silt \% & 28.13 \\
Clay \% & 39.00 \\
Soil texture \% & Clay loam \\
Chemical analysis & \\
PH \% & 7.65 \\
CaCo3 \% & 1.38 \\
Organic matter \% & 1.65 \\
Available N, ppm & 1.50 \\
Available p, ppm & 1.81 \\
Available k, ppm & 135.45 \\
\hline
\end{tabular}

The experimental design was split plot design with three replications. The main plots were devoted for seeding rates, whereas, nitrogen fertilizer rates occupied the sub plots.

The plot area was $10.5 \mathrm{~m}^{2}$ (15 rows, $3.5 \mathrm{~m}$ length at a distance at 20 $\mathrm{cm}$ apart). The preceding summer crop in the two seasons was maize.

The treatments were as follows:

A- Main plots (seeding rates)

$-100 \%$ wheat $\left(60 \mathrm{~kg} \mathrm{fed}^{-1}\right)+15 \%$ fahl berseem $\left(3 \mathrm{~kg} \mathrm{fed}^{-1}\right)$.

$-100 \%$ wheat $\left(60 \mathrm{~kg} \mathrm{fed}^{-1}\right)+25 \%$ fahl berseem $\left(5 \mathrm{~kg} \mathrm{fed}^{-1}\right)$.

$-100 \%$ wheat $\left(60 \mathrm{~kg} \mathrm{fed}^{-1}\right)+35 \%$ fahl berseem $\left(7 \mathrm{~kg} \mathrm{fed}^{-1}\right)$.

B- Sub plots (nitrogen fertilizer rates):

$-100 \%$ of the recommended rate for wheat $\left.\left(75.00 \mathrm{Kg} \mathrm{N}^{-1}\right)^{-1}\right)$.

$-75 \%$ of the recommended rate for wheat $\left(56.25 \mathrm{Kg} \mathrm{N} \mathrm{fed}^{-1}\right)$.

- $50 \%$ of the recommended rate for wheat $\left(37.50 \mathrm{Kg} \mathrm{N} \mathrm{fed}^{-1}\right)$.

Pure stand of wheat cv. Sakha 93 and fahl berseem were sown at a rate of $60 \mathrm{~kg} \mathrm{fed}^{-1}$ and $20 \mathrm{~kg} \mathrm{fed}^{-1}$, respectively. Seeds of both crops were sown on November 13th and 19th in 2006/ 2007 and 2007/2008 seasons, respectively.

All experimental units received phosphorus $\left(22.5 \mathrm{Kg} \mathrm{P}_{2} \mathrm{O}_{5} \mathrm{fed}^{-1}\right)$ in the form of calcium super phosphate $\left(15 \% \mathrm{P}_{2} \mathrm{O}_{5}\right)$ during land preparation. Nitrogen fertilizer rates in the form of ammonium nitrate $(33.5 \% \mathrm{~N})$ were applied in three equal rates. The first was added at planting date, the second was at prior first irrigation and the third was at the third irrigation. Cultural management and disease and pest control programs for wheat and fahl berseem crops were followed as recommended by the Egyptian Ministry of Agriculture.

At full growth, twenty plants of wheat, as well as fahl berseem were randomly taken from each sub plot to determine growth characters and yield components. 


\section{Data recorded:}

\section{Wheat:}

Plant height $(\mathrm{cm})$, spike length $(\mathrm{cm})$, number of spikes $/ \mathrm{m}^{2}$, number of grains/ spike, weight of grains/spike (g), number of spikelets/spike, 1000grains weight $\left(\mathrm{g}\right.$ ), grain yield in ardab fed ${ }^{-1}$. (ardab equal $150 \mathrm{Kg}$ and one feddan $=4200 \mathrm{~m}^{2}$ )

Fahl berseem data:

Plant height $(\mathrm{cm})$, weight of 1000 seeds $(\mathrm{g})$ and seed yield in ardab fed1. (ardab equal $156 \mathrm{Kg}$.)

At harvest, which took place on 15th and $17^{\text {th }}$ May in the first and second seasons, respectively. The two external rows from each sub plot were eliminated to avoid the border effect. 13 rows were harvested, threshed and their grain yield of wheat and seed yield of fahl berseem were weighted after separation and adjusted to ardab fed ${ }^{-1}$. Straw yield in wheat (pure stand) and in mixture (wheat + fahl berseem) was weighted adjusted to ton fad ${ }^{1}$.

The statistical analysis was carried out according to Snedecor and Cochran (1982) using MSTAT computer V4 (1986). LSD at 0.05 level was used to compare the differences between treatment means.

\section{Competitive relationships}

1- land Equivalent Ratio (LER)

It was described by Mead and Willey (1980) as follows.

Where $Y_{i}{ }^{\prime}=$ yield of crop $i$ in intercropping.

$$
\text { LER }=\sum_{1=1}{ }^{n}\left(Y_{i} 1 / Y_{i}{ }^{M}\right)
$$

$Y_{i}{ }^{M}=$ yield of crop i in monocropping

$\mathrm{n}=$ number of crops in the intercropping system

\section{2-Competition Ratio (CR)}

It is based on yield and space assigned to each species in an intercropping system (Mason et al., 1986). From the definition, the term CR is therefore the ratio of the particular LERs of two intercrops, but corrected for the sown proportion of either crop (Willey and Rao, 1980). The CR of crop $B$ is the reciprocal of the CR of crop $A$.

\section{CR $=\left(\right.$ LER $_{A} /$ LER $\left._{B}\right)\left(S_{B} / S_{A}\right)$}

Where: $S_{A}=$ relative space occupied by crop $A$ $S_{B}=$ relative space occupied by crop $B$

The net income fed $^{-1}$ was calculated for each treatment in Egyptian pounds, using the average market prices for both years. The average market prices were $260 \mathrm{~L}^{-E}$ ardab $^{-1}$ for wheat grains and 320 L.E of straw ton $^{-1}$ and 1560 L.E ardab $^{-1}$ for seeds of fahl berseem according to farm price. 


\section{RESULTS AND DISCUSSION}

\section{A- Wheat crop}

1- Effect of seeding rate of fahl berseem in mixture with wheat on wheat

Data in Table 2 showed that plant height differed significantly with the different rates of fahl berseem in the mixture, compared to pure stand of wheat in the two seasons. It is clear that wheat plants tended to be higher by increasing the density of fahl berseem in mixture with wheat, more over the increase was great enough to reach the $5 \%$ level of significance. These results hold true in both seasons. Regarding spike length, number of spikes $/ \mathrm{m}^{2}$ and number of grains/spike, significant differences were observed in the two seasons as compared to solid planting of wheat. Data indicated that the means of these characters decreased by increasing fahl berseem density in the mixture. In the first season, these decreases were estimated for spike length by 3,4 and $6 \%$; for number of spikes $/ \mathrm{m}^{2}$; the decreases were 2, 4 and $11 \%$; for number of grains/ spike the decreases were 3, 9 and $19 \%$ when the rate of fahl berseem in the mixture was 15,25 and $35 \%$. On the other hand these reductions were 4,6 and $9 \%$ for number of spikes $/ \mathrm{m}^{2}$ and 4,8 and $17 \%$ for number of grains/spike. These trends were not regular for spike length in the second season. With respect to weight of grains/spike and straw yield of mixture fed ${ }^{-1}$, the differences between treatments were significant in the first season only, but they did not reach to the $5 \%$ level of significance in the second season, although trend followed the general tendency of the previous traits.

Table 2: Effect of seeding rates of fahl berseem in mixture with wheat on wheat characters in 2006/2007 and 2007/2008 seasons.

\begin{tabular}{|c|c|c|c|c|c|c|c|c|c|}
\hline Characters & $\begin{array}{c}\text { Plant } \\
\text { height } \\
(\mathrm{cm})\end{array}$ & $\begin{array}{c}\text { No. of } \\
\text { spikes/ } \\
\mathrm{m}^{2}\end{array}$ & $\begin{array}{c}\text { Spike } \\
\text { length } \\
\text { (cm) }\end{array}$ & $\begin{array}{c}\text { No. of } \\
\text { spikelets } \\
\text { /spike }\end{array}$ & $\begin{array}{c}\text { No. of } \\
\text { grains/ } \\
\text { spike }\end{array}$ & $\begin{array}{c}\text { Weight } \\
\text { of } \\
\text { grains/ } \\
\text { Spike } \\
\text { (g) }\end{array}$ & $\begin{array}{c}1000 \\
\text { grain } \\
\text { weight } \\
\text { (g) }\end{array}$ & $\begin{array}{c}\text { Grain } \\
\text { yield } \\
\text { ardabfe } \\
\mathrm{d}^{-1}\end{array}$ & $\begin{array}{c}\text { Straw } \\
\text { yield } \\
\text { ton } \\
\text { fed }\end{array}$ \\
\hline Treatments
\end{tabular}

Data in Table 2 also showed that the number of spikelets /spike had also the same trend like number of grains/ spike. 1000-grain weight and grain yield fed ${ }^{-1}$ were significantly affected by seeding rates of fahl berseem in 
mixture with wheat in the first and second seasons. Data in Table 2 also evidenced that mixing $15 \%$ of fahl berseem with wheat gave the highest values of 1000 -grain weight compared to the pure stand. Mixing $15 \%$ fahl berseem with wheat gave an increase in grain yield fed ${ }^{-1}$ amounted to $9 \%$ and $10 \%$ compared to the treatment of mixing $35 \%$ of fahl berseem in the two seasons, respectively. The same trend was observed for straw yield of mixture fed ${ }^{-1}$. Similar results were obtained by Kamel et al. (1991), AbouKresha et al. (1996) and Abou- Kresha et al. (2008). Thorsted et al. (2006) showed that intercropping winter wheat and white clover decreased wheat grain yield by $10-25 \%$ as compared with wheat sole cropping. The yield reductions in mixtures were likely caused by intera-specific and intracompetition for light, nutrients and water during vegetative growth and during grain filling period.

\section{2- Effect of nitrogen rates on wheat characters.}

The effect of nitrogen rates on wheat characters is shown in Table 3. Data indicated that nitrogen rates had significant effects on growth, yield and its components of wheat in the two seasons. Results showed that the values of all the studied characters of wheat decreased by decreasing nitrogen rates less than the $(100 \%)$ of the recommended dose. The reduction on grain yield fed $^{-1}$ was 1.61 and 1.43 ardab fed $^{-1}$ when nitrogen level decreased from $100 \%$ to $75 \%$ in the first and second seasons respectively. Whereas, this reduction was 2.96 and 2.45 ardab fed $^{1}$ when nitrogen rates decreased from $100 \%$ to $50 \%$ in the first and second seasons, respectively. It is well known the important role of nitrogen in stimulating the meristematic activity and synthesizing protein cells which in turn increase growth, yield and its components of wheat. Similar results were obtained by Zahera and Seif ELNasr (1993) they found that growth, yield and its components of wheat were improved with the higher rate of nitrogen fertilizer up to $80 \mathrm{~kg} \mathrm{~N} \mathrm{fed}^{-1}$.

Table 3: Effect of nitrogen rates on growth yield and yield Components of wheat in 2006/2007 and 2007/2008 seasons.

\begin{tabular}{|c|c|c|c|c|c|c|c|c|}
\hline Characters & $\begin{array}{l}\text { Plant No. of } \\
\text { height spikes/ } \\
\text { (cm) } \mathbf{m}^{2}\end{array}$ & $\begin{array}{l}\text { Spike } \\
\text { length } \\
(\mathrm{cm})\end{array}$ & $\begin{array}{l}\text { No. of } \\
\text { spikelets } \\
\text { /spike }\end{array}$ & $\begin{array}{l}\text { No. of } \\
\text { grains/ } \\
\text { spike }\end{array}$ & $\begin{array}{l}\text { Weight } \\
\text { of } \\
\text { grains/ } \\
\text { Spike } \\
\text { (g) }\end{array}$ & $\begin{array}{l}1000 \\
\text { grain } \\
\text { weight } \\
\text { (g) }\end{array}$ & $\begin{array}{l}\text { Grain yield } \\
\text { ardabfed }^{-1}\end{array}$ & $\begin{array}{c}\text { Straw } \\
\text { yield } \\
\text { ton fed-1 }^{-1}\end{array}$ \\
\hline $\begin{array}{|ll|}\begin{array}{l}\text { Nitrogen } \\
\text { rates }\end{array} & \text { fertilizer } \\
\end{array}$ & \multicolumn{8}{|c|}{$2006 / 2007$} \\
\hline $75.00 \mathrm{Kg}$ & 112.00410 .16 & 12.15 & 18.15 & 49.10 & 2.71 & 44.44 & 22.49 & 5.09 \\
\hline $56.25 \mathrm{Kg}$ & 109.81392 .28 & 12.00 & 17.84 & 47.23 & 2.58 & 43.39 & 20.88 & 4.64 \\
\hline $37.50 \mathrm{Kg}$ & 107.84372 .49 & 11.80 & 17.54 & 45.54 & 2.42 & 40.68 & 19.53 & 4.24 \\
\hline \multirow[t]{2}{*}{ LSD 5\% } & 2.76 & 0.11 & 0.10 & 0.18 & 0.03 & 0.98 & 0.12 & 0.04 \\
\hline & \multicolumn{8}{|c|}{$2007 / 2008$} \\
\hline $75.00 \mathrm{Kg}$ & 112.22424 .23 & 12.16 & 18.27 & 50.54 & 2.76 & 46.46 & 23.18 & 5.20 \\
\hline $56.25 \mathrm{Kg}$ & 110.23405 .18 & 11.86 & 18.03 & 48.66 & 2.64 & 44.74 & 21.75 & 4.78 \\
\hline $37.5 \mathrm{Kg}$ & 108.21387 .04 & 11.55 & 17.76 & 46.61 & 2.49 & 43.06 & 20.73 & 4.51 \\
\hline LSD 5\% & 0.39 & 0.05 & 0.07 & 0.33 & 0.02 & 0.30 & 0.29 & 0.06 \\
\hline
\end{tabular}




\section{3- Effect of interaction between seeding rates of fahl berseem in mixture} with wheat and nitrogen rates on wheat characters.

Data in Table 4 showed that seeding rates of fahl berseem in mixture with wheat $x$ nitrogen rates interaction had a significant effect on plant height, grain yield fed-1 of wheat and straw yield of mixture fed-1 in the first and second seasons. The data also, indicated that the monoculture had higher values compared to all rates of seeding of fahl berseem. Data indicated that mixing $15 \%$ of fahl berseem with wheat fertilized by the recommended rate $(100 \%)$ of nitrogen fertilizer $\left(75 \mathrm{~kg} \mathrm{~N} \mathrm{fed}^{-1}\right)$ gave the highest values of grain and straw yields of mixture fed ${ }^{-1}$. compared to the other treatments in the two seasons. With respect to plant height, the highest values (113.20 and $113.68 \mathrm{~cm}$.) were obtained when wheat was sown in mixture with fahl berseem at a rate of $35 \%$ of the recommended rate for seeding and fertilized with the recommended rate of nitrogen fertilizer in the first and second seasons, respectively.

Table 4: Effect of interaction between seeding rates of fahl berseem in mixture with wheat and nitrogen rates on wheat characters in 2006/2007 and 2007/2008 seasons.

\begin{tabular}{|c|c|c|c|c|c|c|c|}
\hline Treatments & cters & $\begin{array}{r}\text { Plant I } \\
\text { (cr }\end{array}$ & $\begin{array}{l}\text { height } \\
\text { m) }\end{array}$ & $\begin{array}{l}\text { Grain } \\
\text { ardak }\end{array}$ & $\begin{array}{l}\text { yield } \\
\text { fed }^{-1}\end{array}$ & $\begin{array}{c}\text { Stran } \\
\text { ton }\end{array}$ & $\begin{array}{l}\text { yield } \\
\text { fed }^{-1}\end{array}$ \\
\hline $\begin{array}{l}\text { Mixed } \\
\text { cropping }\end{array}$ & N. rates & 2006/2007 & $2007 / 2008$ & $2006 / 2007$ & $2007 / 2008$ & $2006 / 2007$ & $2007 / 2008$ \\
\hline $100 \%$ W heat & $\begin{array}{c}75.00 \\
\mathrm{Kg}\end{array}$ & 117.35 & 115.45 & 23.22 & 24.75 & 5.51 & 5.58 \\
\hline & $\begin{array}{c}56.25 \\
\mathrm{Kg}\end{array}$ & 115.04 & 113.29 & 21.72 & 23.08 & 4.97 & 5.13 \\
\hline & $\begin{array}{c}37.50 \\
\mathrm{Kg}\end{array}$ & 112.39 & 110.55 & 20.79 & 21.94 & 4.37 & 4.88 \\
\hline $\begin{array}{l}100 \% \mathrm{~W} \\
15 \% \mathrm{~F}\end{array}$ & $\begin{array}{c}75.00 \\
\mathrm{Kg}\end{array}$ & 107.83 & 109.22 & 22.57 & 23.39 & 5.07 & 5.25 \\
\hline berseem & $\begin{array}{c}56.25 \\
\mathrm{Kg}\end{array}$ & 106.25 & 107.85 & 21.14 & 22.24 & 4.73 & 4.87 \\
\hline & $\begin{array}{c}37.50 \\
\mathrm{Kg}\end{array}$ & 105.56 & 106.48 & 19.91 & 21.11 & 4.29 & 4.58 \\
\hline $\begin{array}{l}100 \% \mathrm{~W}: 25 \% \\
F \text { berseem }\end{array}$ & $\begin{array}{c}75.00 \\
\mathrm{Kg}\end{array}$ & 109.63 & 110.54 & 21.76 & 22.28 & 5.07 & 4.97 \\
\hline & $\begin{array}{c}56.25 \\
\mathrm{Kg}\end{array}$ & 106.87 & 108.55 & 20.72 & 20.94 & 4.54 & 4.67 \\
\hline & $\begin{array}{c}37.50 \\
\mathrm{Kg}\end{array}$ & 104.83 & 106.11 & 19.43 & 20.03 & 4.25 & 4.39 \\
\hline $\begin{array}{l}100 \% \mathrm{~W}: \\
35 \% \mathrm{~F}\end{array}$ & $\begin{array}{c}75.00 \\
\mathrm{Kg}\end{array}$ & 113.20 & 113.68 & 21.09 & 22.30 & 4.69 & 5.02 \\
\hline berseem & $\begin{array}{c}56.25 \\
\mathrm{Kg}\end{array}$ & 111.08 & 111.23 & 19.61 & 20.75 & 4.32 & 4.44 \\
\hline & $\begin{array}{c}37.50 \\
\mathrm{Kg}\end{array}$ & 108.56 & 109.69 & 19.01 & 19.83 & 4.03 & 4.19 \\
\hline LSD 5\% & & 0.78 & 0.56 & 0.24 & 0.57 & 0.07 & 0.13 \\
\hline
\end{tabular}


B- Fahl berseem crop

1- Effect of seeding rates of fahl berseem on mixture with wheat on fahl berseem

Data in Table 5 showed that different rates of fahl berseem in the mixture had significant effect on plant height, and seed yield fed ${ }^{-1}$ of fahl berseem in the first and second seasons, but it had significant effect on weight of 1000 seed of fahl berseem in the second season only. The obtained data indicated that growth and seed yield fed $^{-1}$ increased by increasing the percentage of seeding fahl berseem mixed with wheat. It is clear that mixing $35 \%$ of fahl berseem seeds with wheat caused an increase in seed yield of fahl berseem estimated by $69 \%$ and $56 \%$ compared to mixing $15 \%$ of the recommended rates of fahl berseem in the first and second seasons, respectively. Results obtained by Kamel et al. (1991) were in agreement with these results. It is clear that the monoculture of fahl berseem had higher value than all mixtures in all the studied characters except in case of weight of 1000 seeds. It is also evident that weight of 1000 seeds although the treatment imposed had no any significant difference in the first season, yet, values tended to decrease regularly and consistently with increasing fahl berseem percentage in the mixture in both seasons.

Table 5: Effect of seeding rates of fahl berseem in mixture with wheat on fahl berseem in 2006/2007 and 2007/2008 season

\begin{tabular}{|c|c|c|c|}
\hline \begin{tabular}{|ll} 
Treatments & Characters \\
\end{tabular} & $\begin{array}{l}\text { Plant height } \\
(\mathrm{cm})\end{array}$ & $\begin{array}{c}\text { Weight of 1000-seed } \\
(\mathrm{g})\end{array}$ & $\begin{array}{c}\text { Seed yield } \\
\left.\text { (ardab fed }^{-1}\right)\end{array}$ \\
\hline Mixed cropping & \multicolumn{3}{|c|}{$2006 / 2007$} \\
\hline $100 \%$ fahl berseem & 111.03 & 3.59 & 1.67 \\
\hline $100 \%$ wheat : $15 \%$ fahl berseem & 96.74 & 3.81 & 0.48 \\
\hline $100 \%$ wheat : $25 \%$ fahl berseem & 100.16 & 3.75 & 0.63 \\
\hline $100 \%$ wheat : $35 \%$ fahl berseem & 105.82 & 3.55 & 0.81 \\
\hline \multirow[t]{2}{*}{ LSD 5\% } & 4.29 & NS & 0.03 \\
\hline & \multicolumn{3}{|c|}{$2007 / 2008$} \\
\hline $100 \%$ fahl berseem & 107.62 & 3.65 & 1.81 \\
\hline $100 \%$ wheat : $15 \%$ fahl berseem & 95.92 & 3.82 & 0.54 \\
\hline $100 \%$ wheat : $25 \%$ fahl berseem & 98.52 & 3.60 & 0.64 \\
\hline $100 \%$ wheat : $35 \%$ fahl berseem & 103.85 & 3.41 & 0.84 \\
\hline LSD $5 \%$ & 2.98 & 0.16 & 0.05 \\
\hline
\end{tabular}

Table 6: Effect of nitrogen rates on growth yield and yield components of fahl berseem in 2006/2007 and 2007/2008 seasons.

\begin{tabular}{|c|c|c|c|}
\hline \begin{tabular}{|l|} 
Characters \\
Treatments \\
\end{tabular} & $\begin{array}{l}\text { Plant height } \\
(\mathrm{cm})\end{array}$ & $\begin{array}{c}\text { Weight of 1000-seed } \\
(\mathrm{g})\end{array}$ & $\begin{array}{l}\text { Seed yield } \\
\left.\text { (ardab fed }^{-1}\right)\end{array}$ \\
\hline Nitrogen fertilizer rates & \multicolumn{3}{|c|}{$2006 / 2007$} \\
\hline $75.00 \mathrm{Kg}$ & 106.33 & 3.88 & 0.99 \\
\hline $56.25 \mathrm{Kg}$ & 103.37 & 3.68 & 0.88 \\
\hline $37.50 \mathrm{Kg}$ & 100.60 & 3.46 & 0.82 \\
\hline \multirow[t]{2}{*}{ LSD 5\% } & 0.51 & 0.03 & 0.02 \\
\hline & \multicolumn{3}{|c|}{$2007 / 2008$} \\
\hline $75.00 \mathrm{Kg}$ & 103.59 & 3.78 & 1.03 \\
\hline $56.25 \mathrm{Kg}$ & 101.41 & 3.62 & 0.96 \\
\hline $37.50 \mathrm{Kg}$ & 99.43 & 3.45 & 0.88 \\
\hline LSD 5\% & 0.35 & NS & 0.02 \\
\hline
\end{tabular}




\section{2- Effect of nitrogen rates on fahl berseem characters}

Table 6 shows the effect of nitrogen rates on fahl berseem characters in $2006 / 2007$ and $2007 / 2008$ seasons. The data indicated that plant height, and seed yield fed $^{-1}$ were significantly affected by nitrogen rates in the two seasons. On the other hand weight of 1000 seed was significantly affected with nitrogen rates in the second season only. It is clear that the fertilization by the recommended rates of nitrogen to wheat in the association gave the highest values of all characters of fahl berseem in the two seasons. On the other hand, the lowest values of these characters were obtained by addition $50 \%$ of the recommended rates of nitrogen fertilizer in the first and second seasons. With respect to seed yield $\mathrm{fed}^{-1}$. of fahl berseem, addition $100 \%$ of the recommended rates of nitrogen fertilizer gave an increase of seed yield estimated to $20 \%$ and $17 \%$ compared to addition of $50 \%$ of the recommended rates in the first and second season, respectively. It is well known the important role of nitrogen in stimulating the meristematic activity and synthesizing protein cells which in turn increase the dry weight of fahl berseem plants (Gabra et al., 1984)

3- Effect of interaction between seeding rates of fahl berseem in mixture with wheat and nitrogen rates on fahl berseem characters.

The interaction effect Table 7 revealed that plant height reached maximum in the mixtures when wheat was mixed with highest rates of fahl berseem and with highest rates of nitrogen. The interaction effect on seed yield $\mathrm{fed}^{1}$. of fahl berseem indicated that the highest yield within mixtures was obtained with $35 \%$ fahl berseem and the highest rates of nitrogen, whereas, the lowest yield was obtained with $15 \%$ fahl berseem and the lowest nitrogen dose. On other hand, higher yields were obtained with solid fahl berseem as compared with all other mixtures but decreased regularly with decreasing nitrogen level within the solid planting

Table 7: Effect of interaction between seeding rates of fahl berseem in mixture with wheat and nitrogen rates on fahl berseem characters in 2006/2007 and 2007/2008 seasons.

\begin{tabular}{|l|c|c|c|c|c|}
\hline \multicolumn{2}{|c|}{ Characters } & \multicolumn{2}{c|}{$\begin{array}{c}\text { Plant height } \\
\text { (cm) }\end{array}$} & \multicolumn{2}{c|}{$\begin{array}{c}\text { Seed yield } \\
\text { (ardab fed }{ }^{-1} \text { ) }\end{array}$} \\
\hline $\begin{array}{l}\text { Mreatments } \\
\text { cropping }\end{array}$ & N. rates & $2006 / 2007$ & $\mathbf{2 0 0 7 / 2 0 0 8}$ & $\mathbf{2 0 0 6 / 2 0 0 7}$ & $\mathbf{2 0 0 7 / 2 0 0 8}$ \\
\hline $100 \%$ fahl & $75.00 \mathrm{Kg}$ & 113.18 & 109.76 & 1.78 & 1.91 \\
berseem & $56.25 \mathrm{Kg}$ & 111.69 & 107.77 & 1.67 & 1.82 \\
& $37.50 \mathrm{Kg}$ & 108.21 & 105.32 & 1.56 & 1.71 \\
\hline $100 \%$ wheat : & $75.00 \mathrm{Kg}$ & 100.93 & 97.62 & 0.57 & 0.62 \\
$15 \%$ fahl & $56.25 \mathrm{Kg}$ & 96.09 & 95.65 & 0.46 & 0.55 \\
berseem & $37.50 \mathrm{Kg}$ & 93.20 & 94.48 & 0.41 & 0.45 \\
\hline $100 \%$ wheat : & $75.00 \mathrm{Kg}$ & 102.89 & 100.76 & 0.72 & 0.69 \\
$25 \%$ fahl & $56.25 \mathrm{Kg}$ & 99.97 & 98.38 & 0.62 & 0.65 \\
berseem & $37.50 \mathrm{Kg}$ & 97.61 & 96.43 & 0.55 & 0.57 \\
\hline $100 \%$ wheat : & $75.00 \mathrm{Kg}$ & 108.33 & 106.22 & 0.88 & 0.90 \\
$35 \%$ fahl & $56.25 \mathrm{Kg}$ & 105.73 & 103.85 & 0.79 & 0.83 \\
berseem & $37.50 \mathrm{Kg}$ & 103.39 & 101.48 & 0.75 & 0.79 \\
\hline LSD 5\% & & 1.01 & 0.70 & 0.05 & 0.09 \\
\hline
\end{tabular}




\section{C- Effect of seeding rates of fahl berseem in mixture with wheat on soil sustainability}

The effect of the inclusion of fahl berseem in the mixture with wheat on soil sustainability are presented in Table 8 , data revealed that organic matter content evidently increased after harvesting the mixture as compared with growing wheat as monoculture. The data also revealed that organic mater content was greater than before planting the mixture, whereas, growing wheat in monoculture resulted in detrimental effect on the organic content as compared to the organic content before planting. Growing mixtures resulted in improving nutritive status of the soil. The data indicated conspicuous increase in nitrogen, phosphorus and potassium content after harvesting the mixtures as compared before planting. On the other hand growing wheat as solid had a deleterious effect on the nutritive status of the soil as compared with before planting wheat. These observations are concordant with those obtained by Jankauskas and Janksuskiene (2003). They reported that legume-cereal mixture is an important sustainable technology compared with continuous cereal cropping, it can increase the stability of soil aggregates, increase available nitrogen and organic mater and decrease soil erosion and emphasized the impotent role of fahl berseem in soil conservation and sustainability.

Table 8: Chemical analysis of the experimental soil at $0-30 \mathrm{~cm}$ depth (Mean of the two seasons)

\begin{tabular}{|l|c|c|c|}
\hline \multirow{2}{*}{} & \multirow{2}{*}{ Before planting } & \multicolumn{2}{|c|}{ After harvest } \\
\cline { 3 - 4 } & & After wheat & After mixtures \\
\hline Chemical analysis & & & \\
PH & 7.65 & 7.66 & 7.61 \\
CaCo3 \% & 1.38 & 1.39 & 1.35 \\
Organic matter \% & 1.65 & 1.63 & 2.20 \\
Available N, ppm & 1.50 & 1.45 & 2.85 \\
Available p, ppm & 1.81 & 1.72 & 2.30 \\
Available k, ppm & 135.45 & 132.40 & 138.90 \\
\hline
\end{tabular}

\section{D- Competitive relationships}

\section{1- land equivalent ratio (LER)}

Data presented in Table 9 indicated that the relative yield (RY) of wheat decreased with increasing the rates of seeding fahl berseem, whereas the RY of fahl berseem increased with increasing these rates. This result is in agreement with those obtained by Kamel et al. (1991). Data also showed that all mixture combinations within any rates of $\mathrm{N}$ fertilizer and fahl berseem led to yield advantage and their LER, exceeded the unit. It could be concluded that the actual productivity was higher than the expected productivity. Land equivalent ratio reached maximum peak when wheat was mixed with $35 \%$ of fahl berseem seeds and fertilized with $100 \%$ of recommended rates. On the other hand the least LER value was associated with growing $15 \%$ of fahl berseem seeds with wheat fertilized by $50 \%$ of the recommended rates of $\mathrm{N}$ fertilizer for wheat. 
J. Agric. Sci. Mansoura Univ., 34 (6), June, 2009

9

6663 
It could be concluded that increasing fahl berseem up to the heaviest rates (35\% of the recommended) resulted in the best land utilization rates. Banik et al. (2006) reported that intercropping wheat and chickpea increased total productivity per unit of land and improved land use efficiency.

\section{2-Competition Ratio (CR)}

The CR term may help identifying the competition balance that is most likely to give maximum yield advantages between component crops (Willey and Rao, 1980). The data indicate that fahl berseem was always more competitive than wheat (Table 9)

\section{Total income}

Effect of seeding rates of fahl berseem in mixture with wheat and nitrogen rates on total income.

Data in Table 9 indicated that the total income when seeding fahl berseem at the rates of $35 \%$ fahl berseem and $75 \mathrm{Kg}$ of Nfed-1 indicated maximum value. Whereas minimum value was obtained when seeding rates of $25 \%$ fahl berseem and $37.5 \mathrm{Kg}$ of N fed $\mathrm{d}^{-1}$. From another angle of data none of the solid cropping treatments could catch up in total income with those obtained from any of the mixtures at the same respective rates of nitrogen fertilizer.

\section{REFERENCES}

Abou-Kerisha, M.A.; M.E. Mousa and M.Abd EL-Hamid (1996). Effect of growing fahl berseem with barley on forage and seed production in middle Egypt. proc. $7^{\text {th }}$ Conf Agronomy Mansoura Univ., 9-10 Sept., 1996, 579-588.

Abou-Kerisha, M.A.; R.A. Gadallah and M.M.A. Badr (2008). Effect of preceding and intercropping crops on yield and yield components of wheat. Minufiya J. Agric. Res., 33 (3): 709-728.

Banik, P.; A. Midya; B.K.Sarker and S.S. Ghose (2006). Wheat and chickpea intercropping system in an additive series experiments advantages and weed smothering. Europ, J. of Agron., 24:325-332.

Cantero-Martineg G.J, Leary and D.J. Connor (1995). Stubble retention and nitrogen in a fallow-wheat rainfed cropping system 1- Soil and nitrogen conservation. Crop growth and yield. Soil Till Res. 34: 79-94.

El-Hattab, A.H.; A.K.Abou- Raya; M.S.Abdel-Raouf; A.Kandil and N.A. Khalil (1985). Forage yield and quality of berseem- grass mixtures as affected by seeding rates and time of cutting. Bull. Fac. Agric. Cario Univ., 36(1): 22-34.

Gabra, M.A.; M.A. Nour EL-Din and E.Z.Youssef (1984). The NPK effect on the yield of berseem/barley mixtures. Proc. EMCIP Symp. Field Crop Res. Inst. Giza, 2(84): 129-136. 
Hussain, T.A. and I.I.Abdel-Latif (1982). Effect of mixed sowing of berseem (Trifolium alexandrinum L.) and barley (Hordium vulgare L.) on the green fodder and dry yield of berseem. Annals of Agric. Sci. Moshtoher, 18: 27-36.

Jankauskas, B. and G. Janksuskiene (2003). Erosion-preventive crop rotation for landscape ecological stability in upland regions of Lithuania, Agric. Ecosep. Environ., 95: 129-142.

Kamel, A.S.; M.A.EL-Masry; M.M.EL-Mihi; I.O. Metwally and A.S. EL-Gamel (1991). Effect of seeding rates of fahl berseem in mixtures of wheat and berseem for seed production. Egypt. J.Appl. Sci., 6(8) 233-238.

Mason,S.C.;D.E.Leihner and J.J.Vorst(1986).Cassava-cowpea and cassavapeanut intercropping.I.Yield and land use efficiency.Agron.J.78: 43-46.

Mahrous, M.A.; M.S. Eisa and A.A. Abd-Alla (1998). Effect of intercropping wheat with lentil at varying nitrogen fertilization rates on yield and their components.Ann. of Agric. Sci, Moshtohor Zagazig Univ., 36(1): 61-69.

Mead, R. and R.W. Willey (1980): The concept of a "land equivalent ratio" and advantages in yield from intercropping. Exp. Agric., 16:217-218.

MSTAT (1986). A Microcomputer Program of the Design Management and Analysis of Agronomic Research Experiments. Michigan State Univ., USA.

Nour EL-Din, M.A., M.A.Gabra and E.Z.Youssef (1984). The Effect of nitrogen fertilization productivity of berseem and barley mixtures. Proc. EMCIP Symp. Field Crop Res. Inst. Giza, 2(84): 122-128.

Norman, D.W. (1972). An economic survey of three villages in Zaria province. II.In put - out put relationships. Ahmedu Bello University. Samara, Nigeria. (C.F. Computer Search).

Schwab, D.S, Fagmeier and W.J, Elliot (1996). Soil and water management system (4thed) John Wiley \& sons. Inc. New York.

Seif, S.A. and S.A. Sedhom (1988). Effect of mixing cereal grasses with fahl berseem on the forage production and botanical fractions. Egypt. J.Appl. Sci., 3(2)204-216.

Snedecor, G.W. and W.G.Cochran (1982). Statistical Methods $6^{\text {th }}$ ed. The lowa State Univ. Pres. Ames., IOWA, USA: 325-330.

Thorsted, M.D.; J.E. Olesen and J.Weiner (2006). Width of clover strips and wheat rows influence grain yield in winter wheat/wheat clover intercropping. Field Crop Res., $95: 280-290$.

Willey, R.W. and M.R. Rao (1980). A competitive ratio for quantifying competition between intercrops. Exp. Agric., 16: 117-126.

Zahera, M. Attia and F.M. Seif EL-Nasr (1993). Effect of some preceding crops on growth, yield and yield components of wheat under two rates of nitrogenous fertilizer. Egypt. J.Appl. Sci., 8(12): 553- 563. 
تأثير خلط معدلات مختلفة من تقاوى البرسيم الفحل مع القمـح تحت ثلاثة مستويات

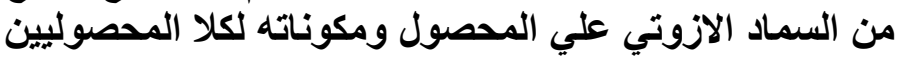

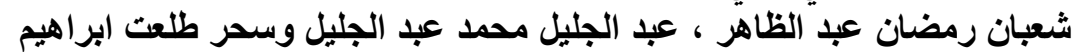

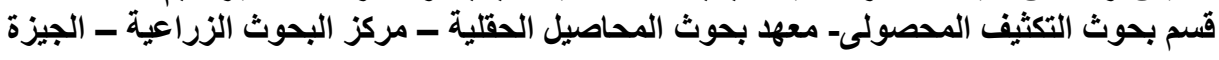

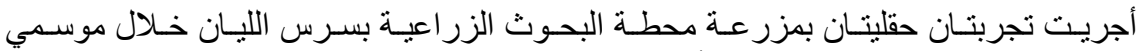

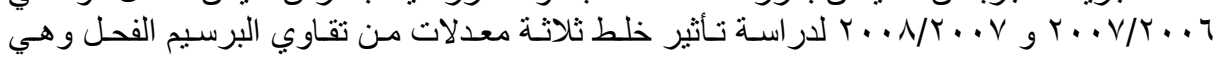

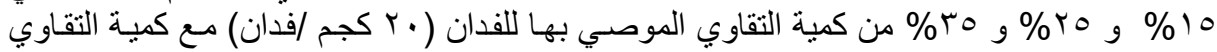

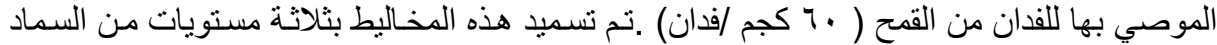

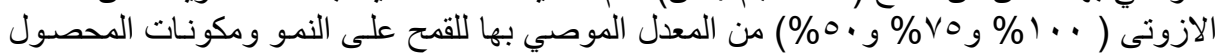
وكميه المحصول لكلا المحصولين. ويمكن تلخيص أهم النتائج المتحصل علئ عليهافيما يلى :-

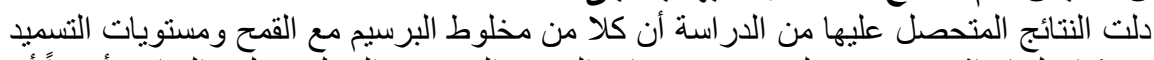

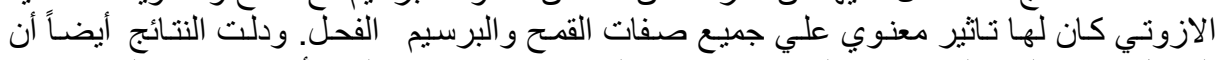

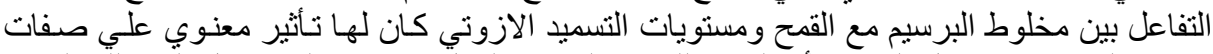

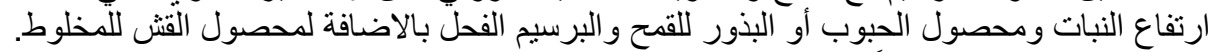

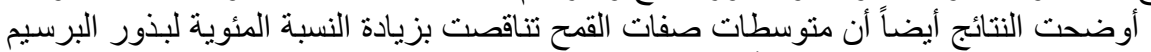

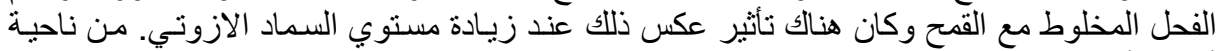

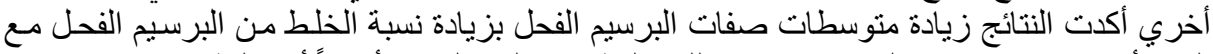

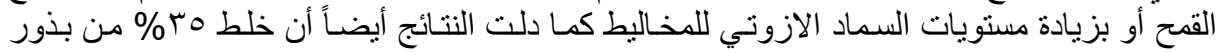

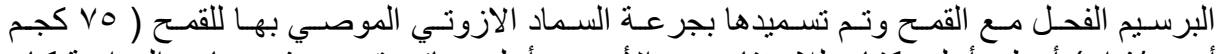

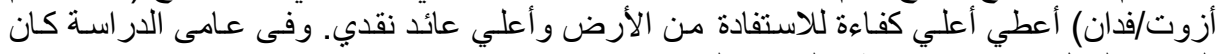
البرسيم الفحل ذو قُرة تتافسية اعلى من القمح. 
Table (9): Effect of seeding rates of fahl berseem in mixture with wheat and nitrogen rates on competitive relationship and total income in 2006/2007 and 2007/2008 seasons.

\begin{tabular}{|c|c|c|c|c|c|c|c|c|c|c|c|c|}
\hline \multicolumn{2}{|c|}{\begin{tabular}{|ll} 
Treatments & Characters \\
\end{tabular}} & \multicolumn{5}{|c|}{$2006 / 2007$} & \multicolumn{5}{|c|}{$2007 / 2008$} & \multirow{3}{*}{\begin{tabular}{|c} 
Total \\
income \\
L.E. \\
Mean \\
from two \\
seasons
\end{tabular}} \\
\hline \multirow[b]{2}{*}{ Mixed cropping } & \multirow[b]{2}{*}{ N. rates } & Relati & ve yield & \multirow{2}{*}{ LER } & \multicolumn{2}{|c|}{ CR } & \multicolumn{2}{|c|}{ Relative yield } & \multirow{2}{*}{ LER } & \multicolumn{2}{|c|}{ CR } & \\
\hline & & Wheat & Berseem & & Wheat & Berseem & Wheat & Berseem & & Wheat & Berseem & \\
\hline \multirow{2}{*}{$\begin{array}{l}100 \% \text { wheat : } 15 \% \text { fah } \\
\text { berseem }\end{array}$} & $\mid \begin{array}{l}75.00 \mathrm{Kg} \\
56.25 \mathrm{Kg}\end{array}$ & $\begin{array}{l}0.97 \\
0.97\end{array}$ & $\begin{array}{l}0.32 \\
0.28\end{array}$ & \begin{tabular}{|l|}
1.29 \\
1.25 \\
\end{tabular} & $\begin{array}{l}0.45 \\
0.52\end{array}$ & $\begin{array}{l}2.21 \\
1.93\end{array}$ & $\begin{array}{l}0.95 \\
0.96\end{array}$ & $\begin{array}{l}0.33 \\
0.30\end{array}$ & $\begin{array}{l}1.28 \\
1.26\end{array}$ & $\begin{array}{l}0.43 \\
0.48\end{array}$ & $\begin{array}{l}2.32 \\
2.10\end{array}$ & \begin{tabular}{|l|}
8554.00 \\
7963.00
\end{tabular} \\
\hline & $37.50 \mathrm{Kg}$ & 096 & 0.26 & 1.22 & 0.55 & 1.81 & 0.96 & 0.26 & 1.22 & 0.55 & 1.81 & 7423.00 \\
\hline \multirow[t]{2}{*}{$\begin{array}{l}100 \% \text { wheat : } 25 \% \\
\text { berseem }\end{array}$} & $1\left|\begin{array}{ll}75.00 \mathrm{Kg} \\
56.25 \mathrm{Kg}\end{array}\right|$ & $\begin{array}{l}0.94 \\
0.95\end{array}$ & $\begin{array}{l}0.41 \\
0.37\end{array}$ & $\begin{array}{l}1.35 \\
1.32\end{array}$ & $\begin{array}{l}0.57 \\
0.64\end{array}$ & $\begin{array}{l}1.74 \\
1.56\end{array}$ & $\begin{array}{l}0.90 \\
0.91\end{array}$ & $\begin{array}{l}0.36 \\
0.36\end{array}$ & $\begin{array}{l}1.26 \\
1.27\end{array}$ & $\begin{array}{l}0.63 \\
0.63\end{array}$ & $\begin{array}{l}1.60 \\
1.58\end{array}$ & $\begin{array}{l}8432.00 \\
7880.00\end{array}$ \\
\hline & $37.50 \mathrm{Kg}$ & 0.93 & 0.35 & 1.28 & 0.66 & 1.51 & 0.91 & 0.33 & 1.24 & 0.69 & 1.45 & 7386.00 \\
\hline \multirow[t]{2}{*}{$\begin{array}{l}100 \% \text { wheat : } 35 \% \\
\text { berseem }\end{array}$} & $\left|\begin{array}{l}75.00 \mathrm{Kg} \\
56.25 \mathrm{Kg}\end{array}\right|$ & $\begin{array}{l}0.91 \\
0.90\end{array}$ & $\begin{array}{l}0.49 \\
0.47\end{array}$ & $\begin{array}{l}1.40 \\
1.37\end{array}$ & $\begin{array}{l}0.65 \\
0.67\end{array}$ & $\begin{array}{l}1.40 \\
1.49\end{array}$ & $\begin{array}{l}0.90 \\
0.90\end{array}$ & $\begin{array}{l}0.47 \\
0.46\end{array}$ & $\begin{array}{l}1.37 \\
1.36\end{array}$ & $\begin{array}{l}0.67 \\
0.68\end{array}$ & $\begin{array}{l}1.49 \\
1.46\end{array}$ & \begin{tabular}{|l|}
8583.00 \\
7912.00
\end{tabular} \\
\hline & $37.50 \mathrm{Kg}$ & 0.91 & 0.48 & 1.39 & 0.66 & 1.50 & 0.90 & 0.46 & 1.36 & 0.68 & 1.46 & 7566.00 \\
\hline \multirow[t]{2}{*}{ Solid crop wheat } & $\left|\begin{array}{l}75.00 \mathrm{Kg} \\
56.25 \mathrm{Kg}\end{array}\right|$ & & & & & & & & & & & $\begin{array}{l}8011.0 \\
7440.0\end{array}$ \\
\hline & $37.50 \mathrm{Kg}$ & & & & & & & & & & & 7035.0 \\
\hline Solid crop fahl berseem & $\left|\begin{array}{l}75.00 \mathrm{Kg} \\
56.25 \mathrm{Kg}\end{array}\right|$ & & & & & & & & & & & $\begin{array}{l}2878.0 \\
2722.0\end{array}$ \\
\hline & 37.50 & & & & & & & & & & & 2551.0 \\
\hline
\end{tabular}

